\title{
Aryloxyphenoxypropionate in association with others herbicides in controlling weedy rice and barnyardgrass
}

\author{
Naiara Guerra ${ }^{1}$, Jaqueline Schmitt² ${ }^{\oplus}$, Helena Zanatta Corrêa ${ }^{1} \oplus$, Regina Pasinatto Visentin ${ }^{1} \oplus$, Wilian Jochem $^{1} \oplus$, \\ Gabriel Dalla Costa $^{1}\left[\right.$, Antonio Mendes de Oliveira Neto ${ }^{3}$, José Alberto Noldin ${ }^{4}[$

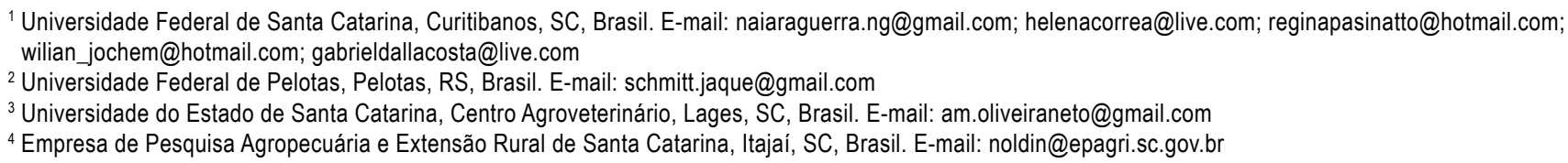

ABSTRACT: The development of aryloxyphenoxypropionate-tolerant rice cultivars made possible the selective use of these herbicides tank mixed with others. Thus, this research aimed to evaluate the applications of aryloxyphenoxypropionates associated with latifolicides for controlling weedy rice and barnyardgrass. In a greenhouse, the weedy rice and barnyardgrass control were evaluated with treatments composed of doses from the graminicides quizalofop-p-ethyl $\left(0 ; 37.5\right.$; and $\left.75 \mathrm{~g} \mathrm{ha}^{-1}\right)$ or haloxyfop-pmethyl $\left(0 ; 45\right.$; and $\left.60 \mathrm{~g} \mathrm{ha}^{-1}\right)$, either isolated or with addition of bentazon, saflufenacil, carfentrazone and with no herbicide. In the field, the effect from doses of quizalofop-p-ethyl (37.5 and $\left.75 \mathrm{~g} \mathrm{ha}^{-1}\right)$ was tested, either isolated or associated with penoxsulam, bispiribac-sodium, quinclorac, propanil, bentazon, saflufenacil, carfentrazone and penoxsulam + bentazon for controlling weedy rice. When using a tank mix of herbicides from the aryloxyphenoxypropionates group with bentazon, saflufenacil or carfentrazone, there was a predominance of antagonistic interactions for weedy-rice, and additives interactions for barnyardgrass. In the field, the mixtures of quizalofop-p-methyl $\left(75 \mathrm{~g} \mathrm{ha}^{-1}\right)$ with penoxsulam, bispiribac, quinclorac, propanil, bentazon, saflufenacil, carfentrazone or penoxsulam + bentazon resulted in excellent control of the weedy-rice.

\section{Ariloxifenoxipropionatos em associação com outros herbicidas no controle}

\section{de arroz-daninho e capim-arroz}

RESUMO: O desenvolvimento de cultivares de arroz tolerante a ariloxifenoxipropionatos possibilitará o uso da mistura destes gramicidas com outros herbicidas de maneira seletiva. Assim, o presente trabalho teve como objetivo avaliar a eficiência da aplicação de ariloxifenoxipropionatos associado a outros herbicidas no controle de arroz-daninho e capim-arroz. Em casa de vegetação avaliou-se o controle de arroz-daninho e capim arroz por meio dos tratamentos compostos por doses dos graminicidas - quizalofop-p-ethyl (0; 37,5 e $\left.75 \mathrm{~g} \mathrm{ha}^{-1}\right)$ ou haloxyfop-p-methyl $\left(0 ; 45 \mathrm{e} 60 \mathrm{~g} \mathrm{ha}^{-1}\right)$, isolados ou associado à bentazon, saflufenacil,

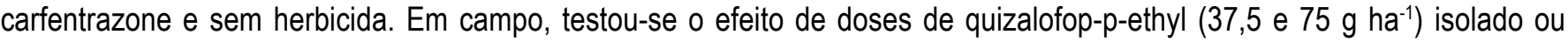
associado a penoxsulam, bispyribac-sodium, quinclorac, propanil, bentazon, saflufenacil, carfentrazone e penoxsulam + bentazon no controle do arroz-daninho. Quando se utilizou a mistura de herbicidas do grupo dos ariloxifenoxipropionatos com bentazon, saflufenacil ou carfentrazone houve predomínio de interações antagônicas para 0 arroz daninho e aditivas para 0 capim-arroz. Em campo, as misturas de quizalofop-p-methyl $\left(75 \mathrm{~g} \mathrm{ha}^{-1}\right)$ com penoxsulam, bispyribac, quinclorac, propanil, bentazon, saflufenacil, carfentrazone ou penoxsulam + bentazon não interferem no controle do arroz-daninho.

Palavras-chave: Echinochloa spp.; haloxyfop-p-methyl; Oryza sativa; quizalofop-p-ethyl; mistura em tanque 


\section{Introduction}

Rice (Oryza sativa) is one of the most produced and consumed cereals worldwide, acting as the main food supply in several regions. Outside Asia, Brazil is its largest producer and consumer, with a production between 11 and 13 million tons in the last harvests (Sosbai, 2018). Most areas are cultivated in a surface irrigation system, with Rio Grande do Sul as the main-producing state, participating with a $70 \%$ share in the national production, followed by Santa Catarina, having from 8.5 to $9.8 \%$ of the national production (Conab, 2018). Rice production can be affected by some factors and among these is the weeds occurrence. Amid the main infesting-weed species of the irrigated rice are the weedy rice (Oryza sativa) and the barnyardgrass (Echinochloa spp.) (Lancaster et al., 2018).

Within the relevant characteristics as a weed, the weedy rice stands out due to its genetic and phenotypic similarities with the cultivated rice, which hinders using the chemical control selectively. The damage caused to the crop profitability can exceed $50 \%$, depending on the infestation density, the implanted cultivar and, mainly, on the number of days coexisting with the crop (Agostinetto et al., 2001).

The barnyardgrass has a high-competitive ability due to its adaptation to the hydromorphic environment, rapid initial growth and the $C_{4}$ photosynthetic cycle (Andres et al., 2007). The presence of one barnyardgrass plant per square meter can reduce the yield of rice grains by up to $22 \%$ depending on the cultivar used and the starting time of the irrigation (Galon et al., 2007). More severe infestations of this weed can result in the impairment of up to $100 \%$ of the grain yield (Agostinetto et al., 2010).

The arrival of the Clearfield ${ }^{\circ}$ technology in Brazil, in the early 2000s, allowed using herbicides from the imidazolinones chemical group (acetolactate synthase inhibitors - ALS) in the irrigated rice crop, thus becoming the main tool for controlling these weed species. However, the great selection pressure caused by continuously using these herbicides caused a rapid increase in the biotypes number of weedy rice (Rubim et al., 2014; Burgos et al., 2014; Dauer et al., 2018) and barnyardgrass (Eberhardt et al., 2016; Rouse et al., 2018) resistant to this herbicides group.

For that matter, new herbicide-resistant rice technologies are under development in order to support the control of grass weeds in the irrigated rice crop, mainly the weedy rice. The Provisia technology (BASF) grants the cultivated rice plants resistance to the herbicide quizalofop-p-ethyl (inhibitor of the enzyme Acetyl CoA carboxylase - ACCase, aryloxyphenoxypropionates group) (Guice et al., 2015). It was developed by traditional breeding methods, through mutations in different gene positions $(1781,1785,1786,1811$, 1824, 1864, 1999, 2027, 2039, 2041, 2049, 2059, 2074, 2075, 2078, 2079, 2080, 2081, 2088, 2095, 2096 or 2098), making the ACCase enzyme insensitive to the herbicides from this said chemical group (Mankin et al., 2014). This technology has been available to rice producers in the United States since 2018 and the projection is that it will be on the Brazilian market in 2022 (BASF, 2018). The Max-Ace technology (RiceTec) also grant resistance to ACCase-inhibiting herbicides (aryloxyphenoxypropionates), through mutation of the G-2096-S gene (Hinga et al., 2013) and it will also be available to the Brazilian producers (Pezzini, 2019).

In Brazil, the Company of Agricultural Research and Rural Extension of Santa Catarina (EPAGRI) developed, through induced mutation (gene G-2027-T), irrigated rice strains that demonstrated high tolerance to the quizalofop-p-ethyl and haloxyfop-p-methyl graminicides (ACCase inhibitors, aryloxyphenoxypropionates group), making it an innovative and promising alternative for controlling weedy rice and barnyardgrass in irrigated rice areas (Andrade et al., 2018).

The development of aryloxyphenoxypropionates-resistant rice materials alters the weed management panorama, since in most cultivated areas the weed community is composed of monocotyledonous and eudicotyledonous species, such as the "cruz-de-malta" or long-leaf willow primrose (Ludwigia longifolia) and the "angiquinho" or jointvetches (Aeschynomene sp.), requiring a mixture of other herbicides to increase the application-control spectrum (Mahajan \& Chauhan, 2015). This situation can result in interaction problems among the herbicides, since research reports the occurrence of antagonism between the mixture of graminicides and other herbicides used in the rice crop (Matzenbacher et al., 2015; Lancaster et al., 2019). According to Zhang et al. (2005), the control of barnyardgrass is reduced when fenoxaprop is applied tank-mixed with tryclopyr, bensulfuron, halosulfuron and carfentrazone.

According to Matzenbacher et al. (2015), the result of the herbicides combination in a tank mix may vary depending on the morphology and the stage of the weed species, the physical-chemical characteristics and the herbicides dose. Therefore, it is of utmost importance determining the compatibility of the association of aryloxyphenoxypropionates with other herbicides in order to develop appropriate application recommendations when the ACCase-inhibitor resistance technology is available to the Brazilian producers. Thus, the present study aimed to evaluate the efficiency of applying aryloxyphenoxypropionates (quizalofop-p-ethyl and haloxyfop-p-methyl) associated with other herbicides in the controlling of weedy rice and barnyardgrass.

\section{Materials and Methods}

\section{Greenhouse experiments}

Four experiments were conducted simultaneously, based on the combination of ACCase-inhibiting herbicides from the aryloxyphenoxypropionate chemical group (quizalofopp-ethyl or haloxyfop-p-methyl) associated with bentazon, saflufenacil or carfentrazone for weedy rice and barnyardgrass species. The conduction period was from March to April 2017, in a greenhouse at the Federal University of Santa Catarina, Curitibanos-SC. 
The completely randomized experimental design was used, with 12 treatments and 5 replicates, arranged in a $3 \mathrm{x}$ 4 factorial design. The first factor was represented by doses from the graminicide - either quizalofop-p-ethyl $10 ; 37.5$ and $75 \mathrm{~g} \mathrm{ha}^{-1}$ ) or haloxyfop-p-methyl (0; 45 and $60 \mathrm{~g} \mathrm{ha}^{-1}$ ), while the second factor was represented for the herbicides bentazon (960 $\mathrm{g} \mathrm{ha}^{-1}$ ), saflufenacil (49 $\mathrm{g} \mathrm{ha}^{-1}$ ), carfentrazone (40 $\mathrm{g} \mathrm{ha}^{-1}$ ) and no latifolicide. The adjuvant from the chemical aliphatichydrocarbons group was added, in the $0.5 \% \mathrm{v} \mathrm{v}^{-1}$ proportion, to the treatments of haloxyfop-p-methyl and the other isolated herbicides. The graminicides doses were chosen based on the dose-response of the aryloxyphenoxypropionate-resistant strain developed by Epagri (Andrade et al., 2018).

The used commercial products were the following: quizalofop-p-ethyl (Targa ${ }^{\circ}, 50 \mathrm{~g} \mathrm{~L}^{-1}$ of active ingredient - a.i., in the emulsifiable concentrate (EC) formulation); haloxyfopp-methyl (Verdict ${ }^{\circ}, 124.7 \mathrm{~g} \mathrm{~L}^{-1}$ of a.i., EC); bentazon (Basagran ${ }^{\bullet}$, $480 \mathrm{~g} \mathrm{~L} \mathrm{~L}^{-1}$ of a.i., soluble concentrate (SL) formulation); saflufenacil (Heat', $700 \mathrm{~g} \mathrm{~kg}^{-1}$ of a.i., dispersible granule (WG ) formulation); carfentrazone (Aurora ${ }^{\circledR}, 400 \mathrm{~g} \mathrm{~L}^{-1}$ of a.i., EC); and adjuvant (Nimbus ${ }^{\circ}, 428 \mathrm{~g} \mathrm{~L}^{-1}, \mathrm{EC}$ ).

Barnyardgrass seeds were acquired at the Experimental Station of Itajaí - Epagri. In order to simulate a weedy rice infestation, the used commercial cultivar was the SCS121 CL, having Clearfield ${ }^{\circledR}$ technology, thus resistant to herbicides from the imidazolinone group. According to Rustom et al. (2018), the sensitivity of the Clearfield ${ }^{\circledR}$ rice cultivars to herbicides is similar to that of weedy rice, which is why they were used in simulating the infestation. These species were sown in pots with capacity for $400 \mathrm{~cm}^{3}$, containing a soil classified as an Haplic "Cambissolo" (Inceptisol) with a clay texture, previously corrected and fertilized, according to the recommendations for the irrigated rice crop (Sosbai, 2018). After the emergence, the thinning performed left three plants per experimental unit.

When the plants were in the $\mathrm{V}_{4}$ stage (four fully expanded leaves), the herbicides were applied through a $\mathrm{CO}_{2}$ pressurized backpack sprayer, equipped with a bar with four flat spray noozles model 110.02 , having a working pressure of $207 \mathrm{kPa}$, travel speed of $1.0 \mathrm{~m} \mathrm{~s}^{-1}$, bar height of $0.5 \mathrm{~m}$ and the application rate of $200 \mathrm{~L} \mathrm{ha}^{-1}$. At the application time, the air temperature was $29.6{ }^{\circ} \mathrm{C}$, the relative humidity was of $55 \%$ and the wind speed was $0.2 \mathrm{~km} \mathrm{~h}^{-1}$.

Prior to the herbicides application, the pots were irrigated daily so that the humidity close to the field capacity was maintained. Twenty-four hours after applying the herbicides, an irrigation to simulate the soil flooding was performed, with a water depth of $2 \mathrm{~cm}$ maintained on the soil throughout the evaluation period for this said purpose.

Evaluations of the weed control were performed visually at 28 days after application (DAA), through assigning scores from 0 to $100 \%$, in which 0 stands for no control and 100 represents the plant death (Kuva et al., 2016). After these control evaluations, the shoot was collected in order to determine the plants dry weight. The collected material, packed in paper bags, was dried in a forced-air circulation oven with temperature set at $60 \stackrel{\circ}{ } \mathrm{C}$, until it reached constant weight.

The data were submitted to analysis of variance by the $F$ test and its means compared by the Tukey test $(p<0.05)$. The control evaluation means were subjected to the model proposed by Colby (1967) for determining the expected result. This in turn was compared with the control percentage obtained by the test $(p<0.05)$. When the comparison between the expected and the observed results was significantly positive, the synergistic effect (+) was considered; when negative, the antagonistic effect (-) was considered; when there was no significant difference between the expected result and the observed, the additive effect. (=) was considered.

\section{Field experiment}

The field experiment was conducted in a systematized area located in Itajaí-SC. The SCS121 CL cultivar was sown, in a pre-germinated system, on November 18, 2015, in order to simulate a high infestation from weedy rice resistant to herbicides from the imidazolinones chemical group (250 plants $\mathrm{m}^{-2}$ ).

The design used was of randomized blocks in a factorial design $(2 \times 9)+1$, with four replications. The first evaluated factor was the quizalofop-p-ethyl graminicide dose (37.5 and $\left.75 \mathrm{~g} \mathrm{ha}^{-1}\right)$, and the second was the herbicides penoxsulam -60 $\mathrm{g} \mathrm{ha}^{-1}$, bispyribac-sodium - $50 \mathrm{~g} \mathrm{ha}^{-1}$, quinclorac - $375 \mathrm{~g} \mathrm{ha}^{-1}$, propanil -3,600 $\mathrm{g} \mathrm{ha}^{-1}$, bentazon - $960 \mathrm{~g} \mathrm{ha}^{-1}$, saflufenacil - 49 $\mathrm{g} \mathrm{ha}^{-1}$, carfentrazone $-40 \mathrm{~g} \mathrm{ha}^{-1}$ and penoxsulam + bentazon $-60+960 \mathrm{~g} \mathrm{ha}^{-1}$, in addition to a control with no herbicide.

The used commercial products were the quizalofopp-ethyl (Targa ${ }^{\circ}, 50 \mathrm{~g} \mathrm{~L}^{-1}, \mathrm{EC}$ ), penoxsulam (Ricer ${ }^{\circ}, 240 \mathrm{~g} \mathrm{~L}^{-1}$, $\mathrm{SC}$ ), bispyribac-sodium (Nominee $, 400 \mathrm{~g} \mathrm{~L}^{-1}, \mathrm{SC}$ ), quinclorac (Facet ${ }^{\circ}, 500 \mathrm{~g} \mathrm{~kg}^{-1}, \mathrm{WP}$ ), propanil (Stam ${ }^{\circledR}, 800 \mathrm{~g} \mathrm{~kg}^{-1}$, WG), bentazon (Basagran , $480 \mathrm{~g} \mathrm{~L}^{-1}, \mathrm{SL}$ ), saflufenacil (Heat ${ }^{\circ}, 700 \mathrm{~g}$ $\mathrm{kg}^{-1}, \mathrm{WG}$ ) and carfentrazone (Aurora ${ }^{\circledR}, 400 \mathrm{~g} \mathrm{~L}^{-1}, \mathrm{EC}$ ).

The experimental units had a total area of $21 \mathrm{~m}^{2}(3 \times 7$ $\mathrm{m})$ and a useful area of $10 \mathrm{~m}^{2}(2 \times 5 \mathrm{~m})$. The herbicides were applied on December 9, 2015, when the weedy rice was in the $\mathrm{V}_{3-4}$ stage (three to four fully expanded leaves), with a $\mathrm{CO}_{2}$-pressurized backpack sprayer containing a bar with four nozzles from the flat-jet model 110.015 , spaced $0.5 \mathrm{~cm}$ apart, having a constant pressure of $207 \mathrm{kPa}$ and the application rate of $150 \mathrm{~L} \mathrm{ha}{ }^{-1}$. The climatic conditions at the application time were air temperature of $28{ }^{\circ} \mathrm{C}$, relative humidity of $85 \%$ and an average wind speed of $1.6 \mathrm{~km} \mathrm{~h}^{-1}$. The herbicides were applied with the soil having been drained, with the fertilization performed 24 hours past the application (30 kg of $\mathrm{N} \mathrm{ha}^{-1}, 30$ $\mathrm{kg}$ of $\mathrm{P}_{2} \mathrm{O}_{5} \mathrm{ha}^{-1}$ and $40 \mathrm{~kg}$ of $\mathrm{K}_{2} \mathrm{O} \mathrm{ha} \mathrm{h}^{-1}$ ) and the area was flooded after 48 hours.

The weedy rice controlling percentage was evaluated at 7 and 28 DAA though assigning scores from 0 to $100 \%$, as previously described. Data were subjected to the analysis of variance by the $\mathrm{F}$ test $(\mathrm{p}<0.05)$. The comparison for the factor quizalofop-p-methyl dose was performed by employing the $F$ test $(p<0.05)$, while the Scott-Knott clustering test $(p<0.05)$ was used for the factor other herbicides. For comparing the 
treatments with the no-herbicide control, the Dunnett test was performed $(p<0.05)$.

\section{Results and Discussion}

\section{Greenhouse experiments}

Weedy rice

Weedy rice was not controlled successfully with the application of bentazon, saflufenacil and isolated carfentrazone, with these results already expected as this species is not in the control spectrum of the said herbicides. Quizalofop-p-ethyl in the lowest isolated dose or associated with carfentrazone also did not promote satisfactory controlling of weedy rice; however, there was a significant increase in the controlling levels of this species when tank mixed with bentazon and saflufenacil. On the other hand, quizalofop-p-methyl at the isolated $75 \mathrm{~g} \mathrm{ha}^{-1}$ dose promoted an excellent weedy rice controlling (99\%), with the same verified when added saflufenacil $(87.4 \%)$ or carfentrazone (99.2\%), although when bentazon was added to mixture the weedy rice controlling was impaired and reached only $33.6 \%$. Increasing the graminicide dose provided greater controlling for the quizalofop-p-pethyl isolated or tank mixed with carfentrazone.

Lancaster et al. (2019) verified control of a weedy rice resistant to inhibitors of ALS greater than $90 \%$ when applied $80 \mathrm{~g} \mathrm{ha}^{-1}$ of quizalofop-p-ethyl, results which are similar to those observed with the $75 \mathrm{~g} \mathrm{ha}^{-1}$ dose. The dry weight of weedy rice plants was reduced when they were treated with quizalofop-p-ethyl (37.5 $\mathrm{g} \mathrm{ha}^{-1}$ ) associated with bentazon and saflufenacil, and for quizalofop-p-methyl (75 $\mathrm{g} \mathrm{ha}^{-1}$ ) isolated and tank mixed with saflufenacil and carfentrazone (Table 1).

The haloxyfop-p-methyl, when isolated or tank mixed, regardless of its dose, resulted in a weedy rice controlling greater than $81.2 \%$. Haloxyfop-p-methyl at a doses of 45 or 60

Table 1. Control (\%) and dry weight ( $\mathrm{g}$ ) of weedy rice at 28 days after applying quizalofop-p-ethyl either isolated or associated with other herbicides. Curitibanos, SC, 2017.

\begin{tabular}{|c|c|c|c|c|c|c|}
\hline \multirow{2}{*}{ Herbicides } & \multicolumn{6}{|c|}{ Dose of quizalofop-p-ethyl (g ha-1) } \\
\hline & \multicolumn{2}{|c|}{0.0} & \multicolumn{2}{|c|}{37.5} & \multicolumn{2}{|c|}{75.0} \\
\hline & \multicolumn{6}{|c|}{ Control (\%) } \\
\hline No herbicide & 0.0 & $\mathrm{cC}$ & 32.6 & $\mathrm{bB}$ & 99.0 & $\mathrm{aA}$ \\
\hline Bentazon & 19.8 & $\mathrm{bC}$ & 89.4 & $\mathrm{aA}$ & 33.6 & bB \\
\hline Saflufenacil & 39.4 & $a B$ & 76.6 & $\mathrm{aA}$ & 87.4 & $\mathrm{aA}$ \\
\hline Carfentrazone & 26.4 & $a b B$ & 29.4 & $b B$ & 99.2 & $\mathrm{aA}$ \\
\hline Fcalc & \multicolumn{6}{|c|}{66.31} \\
\hline \multirow[t]{2}{*}{ CV (\%) } & \multicolumn{6}{|c|}{15.82} \\
\hline & \multicolumn{6}{|c|}{ Dry weight (g) } \\
\hline No herbicide & 0.57 & $\mathrm{aA}$ & 0.49 & $\mathrm{aA}$ & 0.26 & bB \\
\hline Bentazon & 0.52 & $\mathrm{aA}$ & 0.27 & $b B$ & 0.56 & $\mathrm{aA}$ \\
\hline Saflufenacil & 0.43 & $\mathrm{aA}$ & 0.21 & $b B$ & 0.25 & $\mathrm{bAB}$ \\
\hline Carfentrazone & 0.49 & $\mathrm{aA}$ & 0.32 & $a b A B$ & 0.25 & $\mathrm{bB}$ \\
\hline Fcalc & \multicolumn{6}{|c|}{3.87} \\
\hline CV (\%) & \multicolumn{6}{|c|}{33.65} \\
\hline
\end{tabular}

Means followed by the same lowercase letter in the column (other herbicides) and uppercase in the row (doses of quizalofop-p-ethyl) do not differ from each other by the Tukey test at $5 \%$ probability. $\mathrm{g} \mathrm{ha}^{-1}$, in association with bentazon, promoted less controlling than applying the graminicide isolated. There was an effect of the haloxyfop-p-methyl dose only when tank mixed with carfentrazone, where there was a greater controlling when increasing the graminicide dose (Table 2).

The weedy rice dry weight accumulation was reduced with the applications of haloxyfop-p-methyl isolated or associated, regardless of the dose, and of the tank-mixed herbicide. The only exception was for the mixture of haloxyfop-p-methyl (45 $\mathrm{g} \mathrm{ha}^{-1}$ ) with saflufenacil, which resulted in a dry weight less than the isolated graminicide.

The interaction of quizalofop-p-ethyl and haloxyfop-pmethyl with other herbicides in controlling the weedy rice was evaluated according to the equation proposed by Colby (1967) (Table 3). During this procedure, the antagonistic interactions predominated, with this interaction type also occurring for treatments with quizalofop-p-ethyl (37.5 g ha ${ }^{1}$ ) tank mixed with carfentrazone and quizalofop-p-ethyl (75 g $\mathrm{ha}^{-1}$ ) tank mixed with bentazon or saflufenacil. For haloxyfopp-methyl, it occurred in the lowest dose (45 $\mathrm{g} \mathrm{ha}^{-1}$ ), when associated with all herbicides; while on highest dose $(60 \mathrm{~g}$ $\left.\mathrm{ha}^{-1}\right)$, it occured only for bentazon. It was noted that, when bentazon was mixed with haloxyfop-p-methyl, there was an antagonistic effect regardless of the graminicide dose.

Additive effect was verified for quizalofop-p-ethyl (37.5 g $\mathrm{ha}^{-1}$ ) tank mixed with saflufenacil and quizalofop-p-ethyl (75 $\mathrm{g} \mathrm{ha}^{-1}$ ) with carfentrazone, and haloxyfop-p-methyl (60 g ha$\left.{ }^{1}\right)$ with saflufenacil or carfentrazone. Synergistic effect was verified only for quizalofop-p-ethyl (37.5 $\left.\mathrm{g} \mathrm{ha}^{-1}\right)$ with bentazon (Table 3).

These results corroborate with Rustom et al. (2018), who field-tested the controlling of weedy rice and two cultivars of imidazolinones-resistant rice (CL-111 and CLXL-745). These authors observed, at 28 DAA, that quizalofop-p-ethyl (120 g $\left.\mathrm{ha}^{-1}\right)$ in all mixtures with ALS-inhibiting herbicides resulted in

Table 2. Control (\%) and dry weight (g) of weedy rice at 28 days after applying haloxyfop-p-methyl isolated or associated with other herbicides. Curitibanos, SC, 2017.

\begin{tabular}{|c|c|c|c|c|c|c|}
\hline \multirow{2}{*}{ Herbicides } & \multicolumn{6}{|c|}{ Dose of haloxyfop-p-methyl (g ha-1) } \\
\hline & \multicolumn{2}{|c|}{0.0} & \multicolumn{2}{|c|}{45.0} & \multicolumn{2}{|c|}{60.0} \\
\hline & \multicolumn{6}{|c|}{ Control (\%) } \\
\hline No herbicides & 0.0 & $c B$ & 92.0 & $\mathrm{aA}$ & 94.4 & $\mathrm{aA}$ \\
\hline Bentazon & 19.8 & bB & 81.2 & bA & 83.6 & bA \\
\hline Saflufenacil & 39.4 & $a B$ & 85.0 & $a b A$ & 91.4 & $a b A$ \\
\hline Carfentrazone & 26.4 & $b C$ & 82.2 & $a b B$ & 97.2 & $\mathrm{aA}$ \\
\hline Fcalc & \multicolumn{6}{|c|}{17.49} \\
\hline \multirow[t]{2}{*}{ CV (\%) } & \multicolumn{6}{|c|}{9.07} \\
\hline & \multicolumn{6}{|c|}{ Dry weight (g) } \\
\hline No herbicides & 0.57 & $\mathrm{aA}$ & 0.35 & $\mathrm{aB}$ & 0.27 & $\mathrm{aB}$ \\
\hline Bentazon & 0.52 & $\mathrm{aA}$ & 0.22 & $a b B$ & 0.23 & $\mathrm{aB}$ \\
\hline Saflufenacil & 0.43 & $\mathrm{aA}$ & 0.16 & $\mathrm{bB}$ & 0.13 & $\mathrm{aB}$ \\
\hline Carfentrazone & 0.49 & $\mathrm{aA}$ & 0.21 & $a b B$ & 0.11 & $a B$ \\
\hline Fcalc & \multicolumn{6}{|c|}{0.395} \\
\hline CV (\%) & \multicolumn{6}{|c|}{35.84} \\
\hline
\end{tabular}

Means followed by the same lowercase letter in the column (other herbicides) and uppercase in the row (doses of haloxyfop-p-methyl) do not differ from each other by the Tukey test at $5 \%$ probability. 
Table 3. Interaction of mixing quizalofop-p-ethyl and haloxyfop-p-methyl with other herbicides in controlling weedy rice. Curitibanos, SC, 2017.

\begin{tabular}{|c|c|c|c|c|c|}
\hline \multirow{2}{*}{ Herbicides } & \multirow{2}{*}{$\begin{array}{l}\text { Doses } \\
\left(\mathrm{g} \mathrm{ha}^{-1}\right)\end{array}$} & \multicolumn{4}{|c|}{$\%$ Control - 28 DAA } \\
\hline & & Expected $^{1}$ & Observed & $p$ & Interaction \\
\hline Quizalofop + Bentazon & $37.5+960$ & 45.95 & $89.40 * *$ & 0.000 & + \\
\hline Quizalofop + Saflufenacil & $37.5+49$ & 59.16 & 76.60 & 0.104 & $=$ \\
\hline Quizalofop + Bentazon & $75+960$ & 99.20 & $33.60 * *$ & 0.000 & - \\
\hline Quizalofop + Saflufenacil & $75+49$ & 99.40 & $87.40^{*}$ & 0.014 & - \\
\hline Haloxyfop + Saflufenacil & $45+49$ & 95.15 & $85.00 *$ & 0.047 & - \\
\hline Haloxyfop + Carfentrazone & $45+40$ & 94.11 & $82.20 * *$ & 0.001 & - \\
\hline Haloxyfop + Bentazon & $60+960$ & 95.51 & $83.60 * *$ & 0.000 & - \\
\hline Haloxyfop + Saflufenacil & $60+49$ & 96.61 & 91.40 & 0.231 & $=$ \\
\hline Haloxyfop + Carfentrazone & $60+40$ & 95.88 & 97.20 & 0.662 & $=$ \\
\hline
\end{tabular}

Expected result, according to the model proposed by Colby (1967). Significant at the level of * $5 \%$ and ** $1 \%$ probability, according to the o $t$ test. " + ": Synergistic effect; "-": Antagonistic effect and " $=$ ": Additive effect.

antagonistic interaction, in which penoxsulam, penoxsulam + triclopyr and bispyribac reduced the expected controlling from $97 \%$ to one ranging from $59 \%$ to $67 \%$. For tank mixtures of halosulfuron, orthosulfamuron + halosulfuron, orthosulfamuron + quinclorac and imazosulfuron, the controlling levels varied between $81 \%$ and $88 \%$; however, this was also lower than expected, thus characterizing the antagonism. The same abovementioned authors also obtained similar results for the CLCX-745 rice hybrid, confirming once again the antagonism of the used associations. Still according to the authors, the antagonistic interaction negatively affected the irrigated rice yield, in function of the lesser efficiency of the controlling of weedy rice and cultivars simulating it.

\section{Barnyardgrass}

At 28 DAA, the isolated quizalofop-p-ethyl at the $37.5 \mathrm{~g} \mathrm{ha}^{-1}$ dose did not promote a satisfactory barnyardgrass controlling, thus matching with the tank mixture containing carfentrazone. For the quizalofop-p-ethyl, at the $75 \mathrm{~g} \mathrm{ha}^{-1}$ dose, its isolated application or with saflufenacil and carfentrazone lead to totally controlling the barnyardgrass (100\%); however, when associated with bentazon, the control was only $20 \%$.

The increasing quizalofop-p-ethyl dose resulted in an increased controlling of barnyardgrass when applied isolated or in a tank mixture with carfentrazone. In contrast, increasing the dose for the tank mix with bentazon resulted in a reduced control similar to applying it isolated (Table 4). Zhang et al. (2005) did not verify the effect of the increasing fenoxaprop dose when associated with carfentrazone, with an antagonistic effect observed for controlling barnyardgrass, regardless of the used dose, at 30 DAA.

The barnyardgrass dry weight reflected the controlling results, where only the associations with quizalofop-p-ethyl $\left(37.5 \mathrm{~g} \mathrm{ha}^{-1}\right)+$ carfentrazone resulted in a dry weight higher than the isolated graminicide or with the other herbicides. For the graminicide dose of $75 \mathrm{~g} \mathrm{ha}^{-1}$, the tank mix with bentazon demonstrated a dry weight superior to the other treatments.

Increasing the graminicide dose contributed to a reduction in the barnyardgrass dry weight when the combination with
Table 4. Control (\%) and dry weight (g) of barnyardgrass at 28 days after applying quizalofop-p-ethyl isolated or associated with other herbicides. Curitibanos, SC, 2017.

\begin{tabular}{|c|c|c|c|c|c|c|}
\hline \multirow{2}{*}{ Herbicides } & \multicolumn{6}{|c|}{ Dose of quizalofop-p-ethyl $\left(\mathrm{g} \mathrm{ha}^{-1}\right)$} \\
\hline & \multicolumn{2}{|c|}{0.0} & \multicolumn{2}{|c|}{37.5} & \multicolumn{2}{|c|}{75.0} \\
\hline & \multicolumn{6}{|c|}{ Control (\%) } \\
\hline No herbicides & 0.0 & $\mathrm{CC}$ & 25.4 & $b B$ & 100.0 & $\mathrm{aA}$ \\
\hline Bentazon & 10.4 & $b c B$ & 100.0 & aA & 20.0 & $b B$ \\
\hline Saflufenacil & 25.4 & $a b B$ & 100.0 & aA & 100.0 & $\mathrm{aA}$ \\
\hline Carfentrazone & 31.6 & $a B$ & 22.4 & $b B$ & 100.0 & $\mathrm{aA}$ \\
\hline Fcalc & \multicolumn{6}{|c|}{73.65} \\
\hline CV (\%) & \multicolumn{6}{|c|}{19.15} \\
\hline & \multicolumn{6}{|c|}{ Dry weight (g) } \\
\hline No herbicides & 0.61 & $a b A$ & 0.36 & $\mathrm{bB}$ & 0.28 & $b B$ \\
\hline Bentazon & 0.77 & $\mathrm{aA}$ & 0.26 & $\mathrm{bC}$ & 0.57 & $a B$ \\
\hline Saflufenacil & 0.68 & $a b A$ & 0.30 & bB & 0.34 & $b B$ \\
\hline Carfentrazone & 0.55 & bA & 0.61 & $\mathrm{aA}$ & 0.33 & bB \\
\hline Fcalc & \multicolumn{6}{|c|}{7.78} \\
\hline CV (\%) & \multicolumn{6}{|c|}{25.00} \\
\hline
\end{tabular}

Means followed by the same lowercase letter in the column (other herbicides) and uppercase in the row (doses of quizalofop-p-ethyl) do not differ from each other by the Tukey test at $5 \%$ probability.

carfentrazone was used. As for the bentazon, the opposite effect of increasing the dose was verified, resulting in a higher dry weight compared to the $37.5 \mathrm{~g} \mathrm{ha}^{-1}$ dose (Table 4). The high efficiency of the quizalofop-p-ethyl (80 $\left.\mathrm{g} \mathrm{ha}^{-1}\right)$ on the barnyardgrass was validated by Lancaster et al. (2018), where excellent controlling levels (> 92\%) were observed for the 126 evaluated biotypes.

Controlling barnyardgrass with the associations containing haloxyfop-p-methyl, at 28 DAA, regardless of the used dose and herbicide, had $a \geq 96.80 \%$ controlling percentage. However, isolated using the lowest dose (37.5 $\mathrm{g} \mathrm{ha}^{-1}$ ) resulted in a low controlling level (24.50\%), with a positive effect verified from increasing the dose for controlling the barnyardgrass. Regarding the barnyardgrass dry weight, all treatments containing haloxyfop-p-methyl, regardless of the dose and the tank-mixed herbicide, resulted in less dry weight when compared to the treatment with no herbicide and with the other isolated herbicides (Table 5). 
Table 5. Control (\%) and dry weight (g) of barnyardgrass at 28 days after applying haloxyfop-p-methyl isolated or associated with other herbicides. Curitibanos, SC, 2017.

\begin{tabular}{|c|c|c|c|c|c|c|}
\hline \multirow{3}{*}{ Herbicides } & \multicolumn{6}{|c|}{ Dose of haloxyfop-p-methyl $\left(\mathrm{g} \mathrm{ha}^{-1}\right)$} \\
\hline & \multicolumn{2}{|c|}{0.0} & \multicolumn{2}{|c|}{37.5} & \multicolumn{2}{|c|}{75.0} \\
\hline & \multicolumn{6}{|c|}{ Control (\%) } \\
\hline No Herbicides & 0.0 & $\mathrm{cC}$ & 25.4 & $\mathrm{bB}$ & 100.0 & $\mathrm{aA}$ \\
\hline Bentazon & 10.4 & $b c B$ & 96.8 & aA & 99.8 & $\mathrm{aA}$ \\
\hline Saflufenacil & 25.4 & $a b B$ & 100.0 & aA & 100.0 & $\mathrm{aA}$ \\
\hline Carfentrazone & 31.6 & $\mathrm{aB}$ & 100.0 & $\mathrm{aA}$ & 100.0 & $\mathrm{aA}$ \\
\hline Fcalc & \multicolumn{6}{|c|}{18.86} \\
\hline \multirow[t]{2}{*}{ CV (\%) } & \multicolumn{6}{|c|}{15.22} \\
\hline & \multicolumn{6}{|c|}{ Dry weight (g) } \\
\hline No herbicides & 0.61 & $\mathrm{aA}$ & 0.36 & $\mathrm{aB}$ & 0.28 & $\mathrm{aB}$ \\
\hline Bentazon & 0.77 & $\mathrm{aA}$ & 0.38 & $\mathrm{aB}$ & 0.38 & $\mathrm{aB}$ \\
\hline Saflufenacil & 0.68 & $\mathrm{aA}$ & 0.20 & $\mathrm{aB}$ & 0.23 & $\mathrm{aB}$ \\
\hline Carfentrazone & 0.55 & $\mathrm{aA}$ & 0.29 & $\mathrm{aB}$ & 0.14 & $\mathrm{aB}$ \\
\hline Fcalc & \multicolumn{6}{|c|}{1.19} \\
\hline CV (\%) & \multicolumn{6}{|c|}{30.33} \\
\hline
\end{tabular}

Means followed by the same lowercase letter in the column (other herbicides) and uppercase in the row (doses of haloxyfop-p-methyl) do not differ from each other by the Tukey test at $5 \%$ probability.

Concerning the interaction as according to the Colby model (1967), there was no response pattern for the quizalofop-p-ethyl in the barnyardgrass controlling. At the lowest dose (37.5 $\mathrm{g} \mathrm{ha}^{-1}$ ) associated with bentazon or saflufenacil, there was a synergistic interaction. On the other hand, for quizalofop-p-ethyl (37.5 g ha$\left.{ }^{1}\right)$ with carfentrazone and quizalofop-p-ethyl $\left(75 \mathrm{~g} \mathrm{ha}^{-1}\right)$ associated with bentazon, there was antagonistic effect. The highest quizalofop-p-ethyl dose ( $75 \mathrm{~g} \mathrm{ha}^{-1}$ ) associated with carfentrazone or saflufenacil demonstrated additive interactions (Table 6).

Controlling barnyardgrass by using the associations with the haloxyfop-p-methyl, regardless of the dose and the tankmixed herbicide, demonstrated an additive interaction, that is, the effect obtained with the mixtures was similar to what was expected (Table 6). Rustom et al. (2019) found, at 28 DAA, a predominance of additive effect regarding the quizalofop-pethyl (120 $\mathrm{g} \mathrm{ha}^{-1}$ ) mixed with saflufenacil, carfentrazone and thiobencarb; however, for the tank mixture with propanil, the antagonistic effect occurred.
In a study on the efficiency of tank-mix fenoxaprop in controlling the barnyardgrass, Zhang et al., (2005) verified different interaction patterns during this control. According to these authors, the association of fenoxaprop ( $\left.75 \mathrm{~g} \mathrm{ha}^{-1}\right)$ with bentazon or propanil + molinate resulted in additive effect at 10, 20 and 30 DAA; however, when the fenoxaprop dose was increased to $89 \mathrm{~g} \mathrm{ha}^{-1}$, there was antagonism found at 30 DAA with bentazon and at 20 and 30 DAA with propanil + molinate.

Another experiment using a tank mix of ACCase-inhibiting herbicides with ALS-inhibitors under field conditions mostly demonstrated a reduction (64\%) in barnyardgrass controlling (Matzenbacher et al., 2015). The same authors also point out that the mixture with ACCase-inhibiting herbicides is one of the main alternatives for controlling barnyardgrass. However, the association of these herbicides in many situations can compromise the weeds control when compared to the effect of their isolated application.

The weed control reduction when using mixtures of ACCase inhibitors with photosystem II inhibitors is related to reduced absorption. According to Jensen \& Caseley (1990), when bentazon is associated with a graminicide there is a reduction in the absorption of the latter through the cuticle and the plasma membrane, thus reducing the grass-controlling levels. The same was verfiied for barnyardgrass when cyhalofop was joint applied with propanil (Scherder et al., 2005).

In addition to the lesser absorption, other studies show that the translocation of the graminicide is also affected when mixing with other herbicides (Scherder et al., 2005). These authors observed that when applying a mixture of propanil with cyhalofop, from 98.8 to $99.7 \%$ of the applied graminicide remained on the barnyardgrass treated leaf. According to these authors, the lowest translocation occurred due to leaf necrosis caused by propanil, resulting in loss of membrane integrity, which may have led to a reduction in the translocation to other plant tissues.

In essence, the herbicide quizalofop-p-ethyl, either isolated at a $37.5 \mathrm{~g} \mathrm{ha}^{-1}$ dose, was inefficient in controlling weedy rice and barnyardgrass. When quizalofop-p-ethyl (37.5

Table 6. Interaction of mixing quizalofop-p-ethyl and haloxyfop-p-methyl with other herbicides in controlling the barnyardgrass. Curitibanos, SC, 2017.

\begin{tabular}{|c|c|c|c|c|c|}
\hline \multirow{2}{*}{ Herbicides } & \multirow{2}{*}{$\begin{array}{c}\text { Doses } \\
(\text { g i.a.ha-1) }\end{array}$} & \multicolumn{4}{|c|}{$\%$ Control 28 DAA } \\
\hline & & Expected $^{\mathbf{1}}$ & Observed & $p$ & Interaction \\
\hline Quizalofop + Bentazon & $37.5+960$ & 33.16 & $100.00 * *$ & 0.001 & + \\
\hline Quizalofop + Saflufenacil & $37.5+49$ & 44.35 & $100.00 * *$ & 0.001 & + \\
\hline Quizalofop + Bentazon & $75+960$ & 100.00 & $20.00 * *$ & 0.000 & - \\
\hline Quizalofop + Saflufenacil & $75+49$ & 100.00 & 100.00 & & $=$ \\
\hline Haloxyfop + Saflufenacil & $45+49$ & 100.00 & 100.00 & & $=$ \\
\hline Haloxyfop + Carfentrazone & $45+40$ & 100.00 & 100.00 & & $=$ \\
\hline Haloxyfop + Bentazon & $60+960$ & 99.82 & 99.80 & 0.924 & $=$ \\
\hline Haloxyfop + Saflufenacil & $60+49$ & 99.85 & 100.00 & 0.347 & $=$ \\
\hline Haloxyfop + Carfentrazone & $60+40$ & 99.86 & 100.00 & 0.346 & $=$ \\
\hline
\end{tabular}

${ }^{1}$ Expected result, according to the model proposed by Colby (1967). Significant at the level of * $5 \%$ and ** $1 \%$ probability, according to the o $t$ test. " $+"$ : Synergistic effect; "-": Antagonistic effect and " $=$ ": Additive effect. 
$\mathrm{g} \mathrm{ha}^{-1}$ ) was associated with bentazon, there was a synergistic effect, however, when tank mixed with carfentrazone, there was antagonism for both evaluated species. For the highest quizalofop-p-ethyl dose ( $75 \mathrm{~g} \mathrm{ha}^{-1}$ ) associated with bentazon, there was antagonistic effect for both species. Overall, using the highest quizalofop-p-ethyl dose either resulted in antagonistic or additive effect among the evaluated herbicides.

For controlling weedy rice with haloxyfop-p-methyl, an antagonistic effect was found in its lowest dose, regardless of the herbicide mixed with. Yet, when the graminicide dose was increased, there was antagonism only for the mixture with bentazon, while the others demonstrated additive effect. As for the barnyardgrass, all tested mixtures resulted in additive effect.

A greater antagonism occurrence on the weedy rice was noted and this finding is worrisome, since the rice resistance technologies to herbicides from the aryloxyphenoxypropionates chemical group have the controlling of this species as its main objective and these results indicate that this target is more subject to antagonistic interactions when mixing these graminicides with other herbicides.

\section{Field experiment}

In the experiment conducted under field conditions, at 7 DAA, quizalofop-p-ethyl ( $37.5 \mathrm{~g} \mathrm{ha}^{-1}$ ) associated with bentazon was the treatment that better controlled the weedy rice, with indexes over $80 \%$. However, increasing the graminicide dose to $75 \mathrm{~g} \mathrm{ha}^{-1}$ improved the weedy rice controlling, not differing among the other herbicides, with the controlling level ranging from 81.0 to $95.0 \%$. At 28 DAA, for the lowest quizalofop-pethyl dose (37.5 $\mathrm{g} \mathrm{ha}^{-1}$ ), mixtures containing saflufenacil and carfentrazone demonstrated significantly less control than the other treatments. On the other hand, increasing the graminicide dose $\left(75 \mathrm{~g} \mathrm{ha}^{-1}\right)$ was beneficial for the controlling efficiency of the evaluated mixtures, with no difference observed among treatments and with an excellent weedy rice control, ranging from 94.5 to $99.0 \%$ (Table 7).

When using penoxsulam, bispyribac, saflufenacil, carfentrazone or penoxsulam + bentazon, there was a significant effect of the graminicide dose in controlling weedy rice, with an increased graminicide dose from 37.5 to $75.0 \mathrm{~g}$ $\mathrm{ha}^{-1}$, thus resulting in greater control at 28 DAA (Table 7).

Studies developed by Rustom et al. (2018) verified, at 28 DAA, weedy rice controlling ranging from 59 to $88 \%$ when associating quizalofop-p-ethyl (120 $\mathrm{g} \mathrm{ha}^{-1}$ ) with ALSinhibiting herbicides. Lancaster et al. (2019) also evaluated quizalofop-p-ethyl (80 $\mathrm{g} \mathrm{ha}^{-1}$ ) tank mixed with penoxsulan (35 $\mathrm{g} \mathrm{ha}^{-1}$ ), bispyribac (28 $\left.\mathrm{g} \mathrm{ha}^{-1}\right)$, propanil $\left(2,240 \mathrm{~g} \mathrm{ha}^{-1}\right.$ ) and quinclorac ( $283 \mathrm{~g} \mathrm{ha}^{-1}$ ) and found $92,84,87$ and $85 \%$ of weedy rice control, respectively; slightly lower results than those observed in this present experiment. Despite the good results, the authors found controlling levels between 3 and 11\% lower than what was expected for these associations, characterizing the mixtures antagonism.

During the greenhouse experiments, there was frequent antagonism occurrence with the application of quizalofop-
Table 7. Control (\%) of weedy rice after applying quizalofop-pethyl isolated or tank mixed with other herbicides. Itajaí, SC, 2017.

\begin{tabular}{|c|c|c|c|c|}
\hline \multirow{2}{*}{ Herbicides } & \multicolumn{4}{|c|}{ Dose of quizalofop-p-ethyl $\left(\mathrm{g} \mathrm{ha}^{-1}\right)$} \\
\hline & \multicolumn{2}{|c|}{37.5} & \multicolumn{2}{|c|}{75.0} \\
\hline & \multicolumn{4}{|c|}{7 DAA } \\
\hline No herbicides & $* 65.0$ & $\mathrm{~dB}$ & $* 87.2$ & $\mathrm{aA}$ \\
\hline Penoxsulam & $* 67.0$ & $\mathrm{~dB}$ & $* 86.5$ & $\mathrm{aA}$ \\
\hline Bispyribac & *57.2 & $\mathrm{eB}$ & $* 84.0$ & $\mathrm{aA}$ \\
\hline Quinclorac & $* 62.0$ & eB & $* 81.0$ & $\mathrm{aA}$ \\
\hline Propanil & *73.7 & $\mathrm{CB}$ & *89.0 & $\mathrm{aA}$ \\
\hline Bentazon & $* 85.7$ & $\mathrm{aA}$ & $* 91.5$ & $\mathrm{aA}$ \\
\hline Saflufenacil & *79.0 & $\mathrm{bB}$ & *92.5 & $\mathrm{aA}$ \\
\hline Carfentrazone & $* 67.2$ & $\mathrm{~dB}$ & $* 85.7$ & $\mathrm{aA}$ \\
\hline Penoxsulam + Bentazon & *72.5 & $\mathrm{CB}$ & *89.0 & $\mathrm{aA}$ \\
\hline Control with no herbicide & & & & \\
\hline DMS Dunnett & & & & \\
\hline \multirow[t]{2}{*}{ CV (\%) } & & & & \\
\hline & \multicolumn{4}{|c|}{28 DAA } \\
\hline No herbicides & *89.5 & $\mathrm{aA}$ & $* 94.5$ & $\mathrm{aA}$ \\
\hline Penoxsulam & $* 87.5$ & $\mathrm{aB}$ & $* 95.0$ & $\mathrm{aA}$ \\
\hline Bispyribac & $* 88.2$ & $a B$ & $* 95.0$ & $\mathrm{aA}$ \\
\hline Quinclorac & *88.7 & $\mathrm{aA}$ & $* 94.5$ & $\mathrm{aA}$ \\
\hline Propanil & *93.2 & $\mathrm{aA}$ & $* 98.2$ & $\mathrm{aA}$ \\
\hline Bentazon & $* 93.0$ & $\mathrm{aA}$ & $* 97.7$ & $\mathrm{aA}$ \\
\hline Saflufenacil & $* 82.7$ & bB & *99.0 & $\mathrm{aA}$ \\
\hline Carfentrazone & $* 75.0$ & $\mathrm{cB}$ & *99.0 & $\mathrm{aA}$ \\
\hline Penoxsulam + Bentazon & $* 88.2$ & $a B$ & $* 98.0$ & $\mathrm{aA}$ \\
\hline Control with no herbicide & \multicolumn{4}{|c|}{0.0} \\
\hline DMS Dunnett & \multicolumn{4}{|c|}{8.70} \\
\hline CV $(\%)$ & \multicolumn{4}{|c|}{4.73} \\
\hline
\end{tabular}

Means followed by the same lowercase letter in the row (dose of quizalofop-p-methyl) do not differ from each other according to the $F$ test at $5 \%$ probability. Means followed by the same uppercase letter in the column (other herbicides) do not differ from each other according to the Scott-Knott test at $5 \%$ probability. Means preceded by an asterisk "*" differ from the control according to the Dunnett Test at 5\%probability.

p-methyl tank mixed with herbicides, but in most cases, controlling reached satisfactory levels ( $\geq 80 \%$ ). Under field conditions, it was also satisfactory; however, due to the nonapplication of the other isolated herbicides, calculating the occurrence of interaction was not possible.

For controlling weedy rice in a rice crop, it is essential obtaining controlling levels very close to $100 \%$, in order to reduce the chances of cross-fertilization between the cultivated and the weedy rice and the possibility of the tolerance gene passing to the weedy rice. According to some authors, this is the main evolution form of the weedy rice resistance to herbicides (Burgos et al., 2014; Merotto Jr. et al., 2016). Therefore, minimal reduction in controlling due to antagonism can contribute to reducing the useful life from technologies of aryloxyphenoxypropionates-resistant rice.

Alternatives for minimizing the problems due to antagonism among these mixtures would be isolated applying herbicides of different controlling spectrum, respecting intervals between applications or reapplying the herbicides for controlling the control failures occurred due to antagonism (Matzenbacher et al., 2015). However, both alternatives result in an increased cost of weed control. 


\section{Conclusion}

Using herbicides from the aryloxyphenoxypropionates group tank-mixed with bentazon, saflufenacil or carfentrazone resulted in a predominance of antagonistic interactions for weedy rice and additives interactions for barnyardgrass.

Mixtures of quizalofop-p-methyl (75 $\mathrm{g}$ ha $\left.^{-1}\right)$ with penoxsulam, bispyribac, quinclorac, propanil, bentazon, saflufenacil, carfentrazone or penoxsulam + bentazon do not interfere with the weed controlling under field conditions.

\section{Literature Cited}

Agostinetto, D.; Fleck, M.A.; Merotto Júnior, A.; Vidal, R.A. Arroz vermelho: ecofisiologia e estratégias de controle. Ciência Rural. v.31, n.2, p.341-349, 2001. https://doi.org/10.1590/S010384782001000200026 .

Agostinetto, D.; Galon, L.; Silva, J.M.B.V.; Tironi, S.P.; Andres, A. Interferência e nível de dano econômico de capim-arroz sobre o arroz em função do arranjo de plantas da cultura. Planta Daninha, v.28, n.esp., p.993-1003, 2010. https://doi.org/10.1590/S010083582010000500007.

Andrade, A.; Tulmann-Neto, A.; Tcacenco, F.A.; Marschalek, R.; Pereira, A.; Oliveira Neto, A.M.; Scheuermann, K.K.; Wickert, E.; Noldin, J.A. Development of rice (Oryza sativa) lines resistant to aryloxyphenoxypropionate herbicides throught induced mutation with gamma rays. Plant Breeding, v.137, n.3, p.364369, 2018. https://doi.org/10.1111/pbr.12592.

Andres, A.; Concenço, G.; Melo, P.T.B.S.; Schmidt, M.; Resende, R.G. Detecção da resistência de capim-arroz (Echinochloa spp.) ao herbicida quinclorac em regiões orizícolas do Sul do Brasil. Planta Daninha, v.25, n.1, p.221-226, 2007. https://doi.org/10.1590/ S0100-83582007000100025.

BASF. Novo sistema de arroz da Basf deve chegar ao Brasil em 2022. Cultivar. 2018. https://www.grupocultivar.com.br/noticias. 18 Fev. 2019.

Burgos, N.R.; Singh, V.; Tseng, T.M.; Black, H.; Young, N.D.; Huang, Z.; Hyma, K.E.; Gealy, D.R.; Caicedo, A.L. The impact of herbicideresistant rice technology on phenotypic diversity and population structure of United States weedy rice. Plant Physiology, v.166, n.3, p.1208-1220, 2014. https://doi.org/10.1104/pp.114.242719.

Colby, S.R. Calculating synergistic and antagonistic responses of herbicides combinations. Weeds, v.15, n.1, p.20-22, 1967. https://doi.org/10.2307/4041058.

Companhia Nacional de Abastecimento - Conab. Acompanhamento da safra brasileira de grãos. Brasília: Conab, 2019. 113p. (v.6 safra 2018/2019, n.9, nono levantamento). https://www.conab. gov.br/info-agro/safras/graos/boletim-da-safra-de-graos/item/ download/26760_37779459c5d79f63129c8c8c4d634103. 30 Jun. 2019.

Dauer, J.; Hulting, A.; Carlson, D.; Mankin, L.; Harden, J.; MallorySmith, $C$. Gene flow single and stacked herbicide-resistant rice (Oryza sativa) modeling occurrence of multiple herbicideresistant weedy rice. Pest Management Science, v.74, n.2, p. 348355, 2018. https://doi.org/10.1002/ps.4711.
Eberhardt, D.S.; Oliveira Neto, A.M.; Noldin, J.A.; Vanti, R.M. Barnyardgrass with multiple resistance to synthetic auxin, ALS and ACCase inhibitors. Planta Daninha, v.34, n.4, p.823-832, 2016. https://doi.org/10.1590/s0100-83582016340400023.

Galon, L.; Agostinetto, D., Moraes, P.V.D.; Tironi, S.P.; Dal magro, T. Estimativa das perdas de produtividade de grãos em cultivares de arroz (Oryza sativa) pela interferência do capim-arroz (Echinochloa spp.). Planta Daninha, v.25, n.4, p.697-707, 2007. https://doi.org/10.1590/S0100-83582007000400006.

Guice, J.; Youmans, C.; Rhodes, A.; Schultz, J.; Bowe, S.; Armel, G.; Harden, J. Provisia ${ }^{\mathrm{TM}}$ rice system; weed management strategies for rice. In: Annual Meeting Southern Weed Science Society, 68, 2015, Savanna. Proceedings... Savanna: Southern Weed Science Society, 2015. p.197. https://www.swss.ws/wp-content/ uploads/2013/09/Proceedings-of-the-2015-SWSS-Meeting-final. pdf. 22 Jun. 2019.

Hinga, M.; Griffin, S.; Moon, M.S.; Rasmussen, R.D.; Cuevas, F. Methods and compositions to produce rice resistant to ACCase inhibitors. US patent 20130023416A1, 31 January 2013. https://patentimages.storage.googleapis.com/ce/a7/cc/ e84583996467e8/WO2013016210A1.pdf. 18 Jul. 2019.

Jensen, K.I.N.; Caseley, J.C. Antagonistic effects of 2,4-D amine and bentazon on control of Avena fatua with tralkoxydim. Weed Research, v.30, n.6, p.389-395, 1990. https://doi. org/10.1111/j.1365-3180.1990.tb01726.x.

Kuva, M.A.; Salgado, T.P.; Revoredo, T.T.O. Experimentos de eficiência e praticabilidade agronômica com herbicidas. In: Monquero P.A. (Org). Experimentação com herbicidas. São Carlos: RiMa, 2016. p.75-97.

Lancaster, Z.D.; Norsworthy, J.K.; Scott, R.C. Evaluation of quizalofopresistant rice for Arkansas rice production systems. International Journal of Agronomy, v.2018, article 6315865, 2018. https://doi. org/10.1155/2018/6315865.

Lancaster, Z.D.; Norsworthy, J.K.; Scott, R.C.; Gbur, E.E.; Norman, R.J. Evaluation of quizalofop tank-mixture for quizalofopresistant rice. Crop Protection, v.116, p.7-14, 2019. https://doi. org/10.1016/j.cropro.2018.10.004.

Mahajan, G.; Chauhan B.S. Weed control in dry direct-seeded rice using tank mixture of herbicides in South Asia. Crop Protection, v.72, p.90-96, 2015. https://doi.org/10.1016/j. cropro.2015.03.002.

Mankin, S.; Scholf, U.; Hong, H.; Wenck, A.; Neuteboom, L.; Whitt, S.; Carlson, D.R. Herbicide-tolerant plants, US patent 20140045686A1, 13 February 2014. https://patentimages. storage.googleapis.com/5d/b5/1f/c75786c6f97eff/ US20140045686A1.pdf. 18 Jul. 2019.

Matzenbacher, F.O.; Kalsing, A.; Dalazen, G.; Markus, C.; Merotto Jr., A. Antagonism is the predominant effect of herbicide mixture used for imidazolinone resistant barnyardgrass (Echinochloa crus-galli) control. Planta Daninha, v.33, n.3, p.587-597, 2015. https://doi.org/10.1590/S0100-83582015000300021.

Merotto Jr., A.; Goulart, I.C.G.R.; Nunes, A.L.; Kalsing, A.; Markus, C.; Menezes, V.G.; Wander, A.E. Evolutionary and social consequences of introgression of nontransgenic herbicide resistance from rice to weedy rice in Brazil. Evolutionary Applications, v.9, n.7, p.837846, 2016. https://doi.org/10.1111/eva.12387. 
Pezzini, G. RiceTec leva tecnologias Max-Ace e FullPage para a abertura oficial da colheita do arroz do RS. https://www.grupocultivar.com. $\mathrm{br} /$ noticias/ricetec-leva-tecnologias-max-ace-e-fullpage-para-aabertura-oficial-da-colheita-do-arroz-do-rs. 07 Mar. 2019.

Rouse, C.E.; Burgos, N.R.; Norsworthy, J.K.; Tseng, T.; Starkey, C.E.; Scott, R.C. Echinochloa resistance to herbicides continues to increase in Arkansas rice field. Weed Technology, v.32, n.1, p. 3444, 2018. https://doi.org/10.1017/wet.2017.82.

Rubim, R.S.; Agostinetto, D.; Berto-Manica, R.; Fraga, D.S.; Tarouco, C.P. Resistência de biótipos de arroz vermelho aos herbicidas imazapyr + imazapic e alternativas de controle. Revista Ceres, v.61, n.5, p.660667, 2014. https://doi.org/10.1590/0034-737X201461050009.

Rustom, S.Y.; Webster, E.P.; Blouin, D.C.; McKnight, B.M. Interactions between quizalofop-p-ethyl and acetolactate synthase inhibiting herbicides in Acetyl-CoA carboxylase inhibitors-resistant rice production. Weed Technology, v.32, n.3, p.297-303, 2018. https://doi.org/10.1017/wet.2018.15.
Rustom, S.Y.; Webster, E.P.; Blouin, D.C.; McKnight, B.M. Interactions of quizalofop-p-ethyl mixed with contact herbicides in ACCaseresistante rice production. Weed Technology, v.33, n.2, p.233238, 2019. https://doi.org/10.1017/wet.2018.116.

Scherder, E.F.; Talbert, R.E.; Lovelace, M.L. Antagonism of cyhalofop grass activity by halosulfuron, triclopyr, and propanil. Weed Technology, v.19, n.4, p.934-941, 2005. https://doi.org/10.1614/ WT-03-177R2.1.

Sociedade Sul-Brasileira de Arroz Irrigado - Sosbai. Arroz irrigado: recomendações técnicas da pesquisa para o sul do Brasil. Pelotas: Sosbai, 2018. 205p.

Zhang, W.; Webster, E.P.; Blouin, D.C.; Leon, C.T. Fenoxaprop interactions for barnyardgrass (Echinochloa crus-galli) control in rice. Weed Technology, v.19, n.2, p.293-297, 2005. https://doi. org/10.1614/WT-03-250R1. 